\title{
The Impact of Environmental Protection Regulations on Trade Liberalization: Evidence from the Environmental Provisions Under China's Free Trade Agreements
}

\author{
Lu WAN 1 , Yi-zhong FU² and Guan-chu LIU ${ }^{3}$ \\ ${ }^{1,2}$ Beijing Forestry University, Beijing, China \\ ${ }^{3}$ Zhejiang University, Hangzhou, Zhejiang, China
}

\begin{abstract}
Keywords: Environmental Protection Regulations; Free Trade Agreement; Random Effect Model.
\end{abstract}
\begin{abstract}
Based on China's 11 Free Trade Agreements signed with 19 trade partners, this paper discusses how the environmental protection provisions affect trade liberalization. Firstly, it makes use of Chinese merchandise trade data from 2008 to 2015 to analyze the features of trade between China and 19 trade agreement partners. Then it introduces the population, territory area, the distance between China and the trade partners, income difference, social labor productivity, the infrastructure indicators and the environmental protection regulations as independent variables, which builds the extended gravity model to explore the influence of environmental protection regulations. The results of the empirical analysis show that the greater the intensity of related environmental protection is, the larger promotion of trade liberalization will be. Trade agreement partner's infrastructure construction has a positive impact; geographical distance has a negative impact. However, the impact of economic difference is not significant.
\end{abstract}

\section{Introduction}

Environment issue was incorporated into regional trade agreements from the early 1970s. The United States was the first to introduce the environment regulations to the trade agreement, and gradually set up its own high environmental standards to demand its trading partners and dominate environmental domestic and international negotiations (Zhu, 2015) [1]. High environmental standards were mainly reflected in emission standards and taxes (Andreas et al., 2013) [2]. With the development of regional economic integration, environmental issues have gradually attracted the attention [3-4]. Coordinating the relationship between environmental protection and trade liberalization is of high importance to achieve sustainable development of the global economy [5-7]. The impact of the environmental protection on the trade liberalization is reflected in both positive and negative aspects. Environmental protection could enhance the competitive advantage of the domestic environmental protection industry and promote the export of environmentally friendly products [8]. However, high environmental standards will increase the internalization costs [9], reduce the price advantage of products, and hinder the trade liberalization. At the same time, domestic environmental problems can also be transferred to other countries through free trade [10], thus limiting the development of the world economy.

From the perspective of environmental protection regulations under China's Free Trade Agreements, this paper explores its impact on trade liberalization, and proposes corresponding measures to solve the trade environment problems, thus coordinating the development of environmental protection and trade liberalization. Considering that the panel data can help solve the missing variable problem and more effectively increase the accuracy of the estimation, this paper first establishes the fixed effect and the random effect model, and then uses the F test, Hausman test to decide the final use of the random effects model. It makes use of the Chinese trade panel data with 19 trade agreement partners from 2008 to 2015, to build the extended gravity model by introducing the measurement of environmental protection regulations. In order to quantify the environmental regulations, it counts the number of word "environment", the number of words "Sanitation, Health, Plant, Animal, Organism, Agriculture, Forestry" words, the number of environmental provisions, and 
takes Unit GDP Energy Consumption as the indicators of environmental protection regulations.

\section{Development of China's Free Trade Agreements}

China has signed 11 free trade agreements with 19 countries including Australia, Switzerland, Costa Rica, Singapore, Chile, Indonesia, Thailand, Laos, Myanmar, Vietnam, Brunei, Malaysia, Cambodia, Philippines, South Korea, Iceland, Peru, Pakistan and New Zealand. 19 countries are located in Asia, Europe, America and the Pacific. Among them, Singapore, Indonesia, Thailand, Laos, Myanmar, Vietnam, Brunei, Malaysia, Cambodia, Philippines, South Korea and Pakistan are 12 Asian countries. Switzerland and Iceland are 2 European countries; Australia and New Zealand are 2 Pacific countries, and Costa Rica, Chile and Peru are 3 American countries. For the partners of China's FTAs, most of them are developing countries or Asian countries, while developed countries or European/American countries account for a relatively small proportion. These free trade agreements cover a wide range of areas such as trade in goods, trade in services, and investment. China-New Zealand FTA is the first comprehensive free trade agreement between China and other countries covering trade in goods, trade in services, and investment. From 2005 to 2011, the free trade agreements between China and partners had come into effect. In 2014 and 2015, respectively, two FTA agreements came into effect, which means that China had gradually increased its negotiations with trading partners.

Table 1. Statistics on Free Trade Agreements Signed by China

\begin{tabular}{lccc}
\hline \multicolumn{1}{c}{ FTA partners } & $\begin{array}{c}\text { Signature/effective } \\
\text { date }\end{array}$ & Partner economic level & $\begin{array}{c}\text { Geographic } \\
\text { location }\end{array}$ \\
\hline China-ASEAN* & $2002.11 .04 / 2005.01 .01$ & Developed/developing & Asia \\
China-Chile & $2005.11 .18 / 2006.10 .01$ & developing & America \\
China-Pakistan & $2006.11 .24 / 2007.07 .01$ & developing & Asia \\
China-New Zealand & $2008.07 .24 / 2008.10 .01$ & developed & Pacific \\
China-Singapore & $2008.10 .23 / 2009.01 .01$ & developed & Asia \\
China-Peru & $2009.04 .28 / 2010.03 .01$ & developing & America \\
China-Costa Rica & $2010.04 .08 / 2011.08 .01$ & developing & America \\
China-Iceland & $2013.04 .15 / 2014.07 .01$ & developed & Europe \\
China-Switzerland & $2013.07 .06 / 2014.07 .01$ & developed & Europe \\
China-South Korea & $2015.06 .01 / 2015.12 .20$ & developed & Asia \\
China-Australia & $2015.06 .17 / 2015.12 .20$ & developed & Pacific \\
\hline
\end{tabular}

Note: * ASEAN member countries are: Indonesia, Brunei, Vietnam, Myanmar, Laos, Cambodia, Philippines, Malaysia, Singapore, Thailand.

Source: China FTA Service Network and CEPII database.

\section{Environmental Protection Regulations of China's Free Trade Agreements}

China's in force Free trade agreements generally included the chapters of initial provisions, trade in goods, rules of origin, customs procedures and trade facilitation, intellectual property rights, sanitary and phytosanitary measures, technical barriers to trade, trade in services, cooperation, mechanism provisions, dispute settlement and exceptions. Except that the China-Switzerland FTA and the China-Korea FTA contained independent environment chapters, the environmental protection provisions in China's Free Trade Agreements were mainly distributed in rules of origin, sanitary and phytosanitary measures, intellectual property rights, technical barriers to trade, cooperation and exceptions. The free trade agreements between China and Costa Rica (distributed in 20 chapters), Switzerland (26), South Korea (18) and Australia (16) contained more environmental protection provisions. All three partners except Costa Rica were developed countries, which to some extent indicated that developed countries had a strong awareness of environmental protection in trade integration. Free trade agreements with ASEAN (distributed in 2 chapters), Iceland (2) and New 
Zealand (3) had fewer environmental protection provisions, which indicated that Asian countries or developing countries paid less attention to trade environment issues.

Figure 1 shows the analysis results of the environmental protection provisions in China's Free Trade Agreements. The relevant environmental protection provisions mainly involve nine core words: environment, sanitation, health, plant, animal, organism, resources, agriculture and forestry. The words "sanitation" and "plant" were more frequent, while the words "agriculture" and "forestry" were less frequent. This means that free trade agreements paid more attention to health and plant protection, less attention to agriculture and forestry; the core word of direct environmental protection "environment" was in low frequency, while the core word of indirect environmental protection "health" was in high frequency, which indicates that many FTAs focused on weak environmental protection measures to minimize environmental standards and promote the development of free trade. The frequency of each environmental core word in developed countries was higher than that in developing countries, which means that developed countries were more concerned about the environmental problems in free trade cooperation than developing countries, that is, the environmental standards of developed countries were higher than those of developing countries.

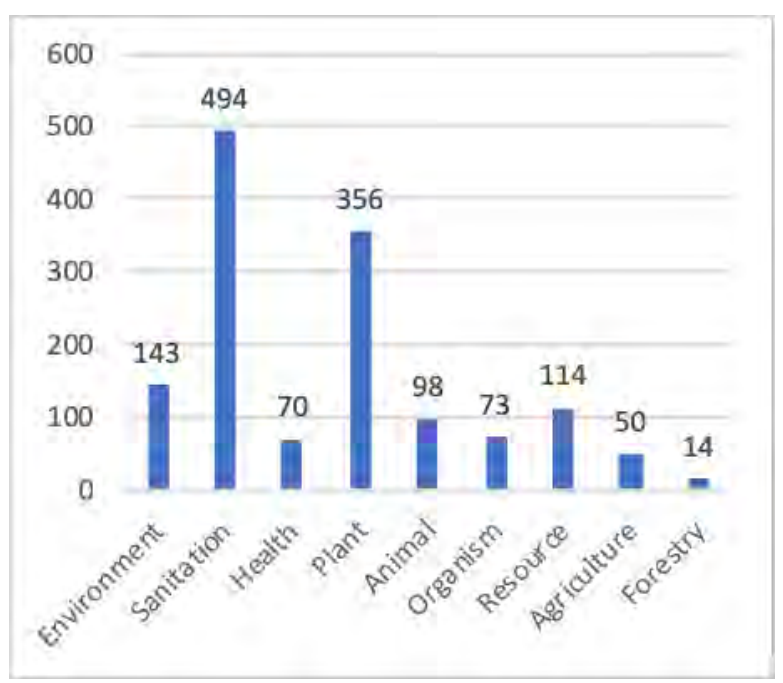

(a)

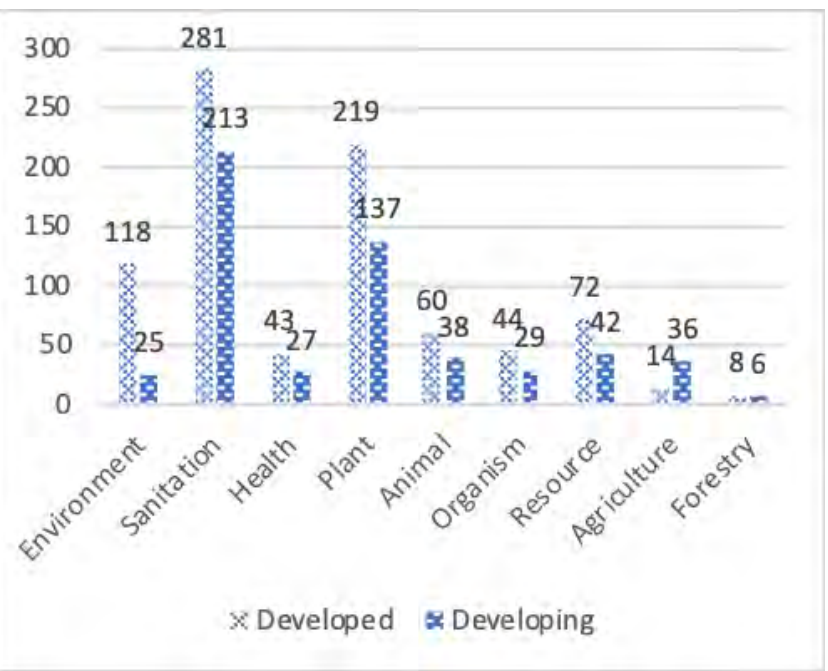

(b)

Source: China FTA Service Network.

Figure 1. The Word Frequency of Environmental Core Vocabulary

\section{Empirical Analysis of the Impact of Environmental Regulations on Trade Liberalization}

Empirical Model and Variables. According to the traditional international trade theory, the factors affecting trade in the basic gravity model mainly include land area, geographical distance, income gap, labor productivity. This paper incorporates environmental protection regulations as an explanatory variable affecting trade and establishes the following extended gravity model (Eq.1).

$$
\begin{aligned}
& \mid \begin{array}{l}
\ln \mid\left(\text { Import }_{i j t}+\text { Export }_{i j t}\right) / \text { GDP }_{i t} \mid=\alpha_{1}+\alpha_{2} \ln \text { Population }_{i t}+\alpha_{3} \ln \text { Population }_{j t}+ \\
\alpha_{4} \ln \text { Land }_{j t}+\alpha_{5} \ln \text { Distance }_{i j}+\alpha_{6} \mid \ln \left(\text { GDPPC }_{i t}\right)-\ln \left(\text { GDPPC }_{j t}\right) \mid+\alpha_{7} \ln \text { Productivity }_{i t}+ \\
\alpha_{8} \ln \text { Railway }_{j t}+\alpha_{9} \ln \text { Port }_{j t}+\alpha_{10} \ln \text { Internet }_{j t}+\alpha_{11} \ln \text { Direct }_{i j t}+\alpha_{12} \ln \text { Indirect }_{i j t}+ \\
\alpha_{13} \ln \text { Environment }_{i j t}+\alpha_{14} \ln E C_{i t}+\varepsilon_{i j t}
\end{array}
\end{aligned}
$$

Wherein, the dependent variable $\ln \mid\left(\right.$ Import $_{i j t}+$ Export $\left._{i j t}\right) / G D P_{i t} \mid$ is trade liberalization. In view of the general measurement of the existing literature and the availability of data, this paper uses the ratio of import and export trade to GDP. For the explanatory variables, Population ${ }_{i t}$ is the population of China; Landjt is the partner country's land area; Population $_{j t}$ is partner country's population; Distance $_{i j}$ is the geographical distance between the two countries; $\left|\ln \left(G D P P C_{i t}\right)-\ln \left(\mathrm{GDPPC}_{\mathrm{jt}}\right)\right|$ is the difference between the per capita GDP of China and the partner country; Productivity ${ }_{i t}$ is the labor productivity of the whole society; Railway ${ }_{j t}$ is the railway infrastructure quality; Port ${ }_{j t}$ is the port infrastructure 
quality; Internet $t_{j t}$ is the Internet usage rate; Direct $_{i j t}$ is the word frequency of "environment"; Indirect $t_{i j t}$ is the words frequency of "Sanitation, Health, Plant, Animal, Organism, Agriculture, Forestry"; Environment $_{i j t}$ is the number of environmental protection provisions; $E C_{i t}$ is China's Unit GDP energy consumption.

Data Sources. The import and export data from 2008 to 2015 is the SITC Rev.3 3-digit code trade data, which comes from the UNCTAD database; the GDP (in 2008 constant dollar), the per capita GDP (in 2008 constant US dollar) and the population are from the World Bank's WDI database; the geographical distance is the linear distance between capitals, which comes from the Google Maps; Chinese national income and the number of employees in the whole society come from the China Statistical Yearbook; the quality of railway infrastructure, port infrastructure and the usage rate of the Internet come from the World Economic Forum's Global Competitiveness Report; China's Free Trade Agreements date comes from China FTA Service Network.

Empirical Results. Firstly, F-statistics are used to test the pooled model and the fixed effect model and select the better model of them; then, LM test is used to select between the pooled model and the random effect model; finally, Hausman test is used to figure out which model to adopt between the fixed effect and random effect model. The P-value of F statistics is 0.0000 , which shows that the fixed effect model is better than the pooled model. The P-value of LM test is 0.0000 , indicating that the random effect model is better than pooled model. Therefore, the pooled model is excluded. In order to determine the final model, we performed Hausman test. The P-value is $0.5561>0.05$, thus we choose the random effect model. The regression results are shown in Table 2.

According to the regression results, we can conclude the impact of environmental protection regulations on trade liberalization under China's FTAs. $\ln$ Population $_{j t}$, $\ln$ Distance $_{i j}$, $\ln$ Railway $_{j t}$, $\ln$ Port $_{j t}, \ln$ Internet $_{j t}$, Direct ${ }_{i j t}$, Environment ${ }_{i j t}, E C_{i t}$ are significant influencing factors. Moreover, Environment $t_{i j t}$ and Direct $_{i j t}$ have a positive impact on trade liberalization with the significance of 5\% and $10 \%$ respectively, that is to say, environmental protection provisions (including direct environmental content) significantly promote the trade liberalization between China and its trade agreement partners. In the meantime, $E C_{i t}$ shows significant negative influence at $1 \%$ level, indicating that the less unit GDP energy consumption, the greater degree of trade liberalization. Unit GDP energy consumption refers to the ratio of total primary energy supply to GDP reflecting the efficiency of energy utilization, further we can conclude that higher efficiency of environmental protection will enhance the level of trade liberalization. In addition, 3 indicators of infrastructure construction show a significant positive effect $\left(\ln\right.$ Railway $_{j t}$ and $\ln$ Internet $_{j t}$ at $1 \%, \ln$ Port $_{j t}$ at $5 \%$ ), which means the railway quality, Internet usage rate, and port quality are very important to China's trade liberalization and play a positive role. Geographical distance has significantly suppressed trade liberalization, while income difference is not significant as well as China's social labor productivity.

Table 2. Regression Results of Random Effects Model

\begin{tabular}{|c|c|c|c|}
\hline Variables & Coefficients & Variables & Coefficients \\
\hline $\ln$ Population $_{\text {it }}$ & 50.72 & lnInternet $_{j t}$ & $5.258 * * *$ \\
\hline $\ln$ Population $_{j t}$ & $-0.764 * * *$ & Direct $_{i j t}$ & $0.262 *$ \\
\hline $\ln L a n d j t$ & -0.00766 & Indirect $_{i j t}$ & 0.310 \\
\hline $\ln$ Distance $_{i j}$ & $-0.624 * * *$ & Environment $_{i j t}$ & $1.842 * *$ \\
\hline $\ln \left(G D P P C_{i t}\right)-\ln \left(\mathrm{GDPPC}_{\mathrm{jt}}\right)$ & -0.0245 & $E C_{i t}$ & $-21.86 * * *$ \\
\hline $\ln$ Productivity $_{i t}$ & -1.909 & _cons & -1027.4 \\
\hline $\ln$ Railway $_{j t}$ & $1.422 * * *$ & $\overline{\mathrm{R}}^{2}$ & - \\
\hline $\ln$ Port $_{j t}$ & $1.084 * *$ & $\mathrm{~N}$ & 86 \\
\hline
\end{tabular}

Note: $* * *$ is significant at $1 \%, * *$ is significant at $5 \%$, and $*$ is significant at $10 \%$.

\section{Conclusion}

Based on the panel data of China and its trade agreement partners from 2008 to 2015, this paper 
uses the random effect model to examine the impact of environmental protection regulations on trade liberalization. The empirical estimation shows that environmental protection provisions (including direct environmental content) significantly affect trade liberalization in a positive way. In the meantime, the environmental efficiency (unit GDP energy consumption) can significantly promote China's trade liberalization. Hence, environmental factors play a crucial role in China's trade liberalization. In addition, the infrastructure construction is very important to China's trade liberalization and play a positive role, however, geographical distance has significantly suppressed trade liberalization. Income difference is not significant as well as China's social labor productivity. Consequently, we propose corresponding suggestions and measures in two aspects. First, China should actively participate in the formulation of international multilateral environmental protection provisions, strengthen international exchanges and strategic policy dialogue in the field of climate change, in order to enjoy the legitimate interests as a developing country. Second, China must reasonably control the unit GDP energy consumption and improve the efficiency of energy utilization, specifically, establish a new green industrial structure, realize the transformation to green economy, develop clean and environmentally friendly energy resources, and reduce pollutant emissions.

\section{Acknowledgement}

This research was financially supported by the Central University Fundamental Science and Research findings of Beijing Forestry University (Project No.: JGZKPY006; 2017ZY57), and the National Social Science Foundation of China (Project No.: 17BJY018).

\section{References}

[1] Y. Zhu, The Development of Environmental Issues in American Regional Trade Agreements from the Perspective of TPP [J]. Journal of Hunan University, 2015, (5): 156-160.

[2] L. Andreas, R. Sascha, S. Michael, Trade and environment: An application of the WIOD database [J]. Chinese Journal of Population Resources and Environmental, 2013, 11 (1): 51-61.

[3] J. Xie, L.Tan, A Study on the Trade Impact of Regional Trade Agreements on Members: Taking China as an Example [J]. International Trade Issues, 2014, (12): 57-67.

[4] Y. Zhou, Enhancing the Environmental Provisions of Free Trade Agreements in the United States and Its impact [J]. Modern International Relations, 2015, (4): 1-7.

[5] S. Muhammad, A. S. Sakiru, O. Ilhan, Environmental Kuznets Curve hypothesis and the role of globalization in selected African countries [J]. Ecological Indicators, 2016, 67 (1): 623-636.

[6] M. E. Hasan, C. Murat, S. Fahri, D. Eyup, The Impact of trade openness on global dioxide emission: Evidence from the top ten emitters among developing countries [J]. Ecological Indicators, 2016, 67 (1): 543-555.

[7] H. L. Thai, H. C. Young, P. Donghyun, Trade openness and environmental quality: International evidence [J]. Energy Policy, 2016, 92 (1): 45-55.

[8] W. Song, G. Li, X. Han. Characteristics of double-link efficiency threshold of environmental regulation, trade liberalization and $R \& D$ innovation: based on panel data analysis of 33 industries in China [J]. International trade issues, 2014 (2): 65-73.

[9] X. Zhang, The Integration of East Asian Regional Trade Agreements and Its Enlightenment to China [J]. Journal of International Business-University of Foreign Economics and Trade, 2015, (3): 76-85.

[10] L. Ren, C. Huang, The impact of domestic and foreign environmental regulations on China's export trade [J]. World Economy, 2015 (5): 59-80. 